\title{
Butterfly communities (Insecta: Lepidoptera) at two recreational areas in Sungai Petani, Kedah, Peninsular Malaysia
}

\author{
NUR IZZAH ATHIRAH BASRI, NURULHUDA ZAKARIA ${ }^{*}$ \\ Faculty of Science and Marine Environment, Universiti Malaysia Terengganu. 21030 Kuala Nerus, Terengganu, Malaysia. Tel.: +60-9-6683720, \\ Fax. +60-9-6683193, vemail: nurul_huda@umt.edu.my
}

Manuscript received: 9 September 2021 Revision accepted: 25 October 2021.

\begin{abstract}
Basri NIA, Zakaria N. 2021. Butterfly communities (Insecta: Lepidoptera) at two recreational areas in Sungai Petani, Kedah, Peninsular Malaysia. Biodiversitas 22: 5039-5046. The knowledge on the butterfly diversity, especially in various habitats in Kedah is still poor. A study was conducted to determine and compare the diversity of butterflies at two recreational areas in Sungai Petani, Kedah, namely Bukit H and Taman Jubli Perak. This study was carried out starting from January 2021 until March 2021 with a total of nine sampling occasions at each site. Visual Encounter Survey (VES) was chosen as a sampling method. The butterflies were captured using a sweep net from $9 \mathrm{am}$ to $11 \mathrm{am}$ and $12 \mathrm{pm}$ to $2 \mathrm{pm}$ for each sampling site. A total of 145 individuals from 13 species from four families of butterflies were recorded. The most abundant species were recorded from the family Nymphalidae. Chilades pandava was the most abundant species obtained from the two recreational areas. From the t-test analysis, there was no significant difference between the diversity of Bukit H and Taman Jubli Perak. Shannon and Simpson's diversity indices showed both sites were interpreted as moderately low in diversity. This may be due to the different types of vegetation that exist at both sampling sites. This study will contribute to the first record of butterflies in Sungai Petani, Kedah, Peninsular Malaysia.
\end{abstract}

Keywords: Butterfly, diversity, insect, northern Peninsular Malaysia, VES

Abbreviations: BH: Bukit H, SSRF: Sungai Sedim Reserve Forest, TPJ: Taman Jubli Perak

\section{INTRODUCTION}

Globally, more than 30 orders of insects have been discovered and classified, including the order Lepidoptera (Hering 2012). Lepidoptera is a diverse order with more than 28,000 species of butterflies, with about $80 \%$ in tropical regions (Khan et al. 2015). Butterflies and moths belong to Order Lepidoptera. Butterflies and moths can be differentiated based on their antennae shape. The shape of butterfly antennae is filiform and club-like, while moth antennae are plumose and feather-like (Stansfield 2016). In terms of behavior, butterflies are an insect that is active during the day (diurnal) compared to moths which are active at night (nocturnal). At rest time, butterflies close their wings upright position while moths hold their wings flat (Williams et al. 2018). The butterfly plays an important role in ecosystems, acting like prey, a pollinator, a seed disperser, a food source and an indicator of the ecosystem's well-being (Nelson 2007; Durairaj and Sinha 2015). Kocher and William (2000) stated that butterflies are useful indicators for ecological research as they are sensitive to habitat disturbance, temperature, light, wind speed, and humidity. However, butterflies are among arthropods that are poorly studied despite being crucial components and indicators of urban ecosystems and biodiversity (Bonebrake and Cooper 2014). There has been a dramatic decline of butterflies that may lead to $40 \%$ of species extinction over the next few decades (Sánchez-Bayo and Wyckhuys 2019).
Butterflies can be found in different types of habitats such as forests, gardens, grasslands and metropolitan areas. In Peninsular Malaysia, there are 1038 species of butterflies recorded (Eliot and Kirton 2000). Many researchers in Malaysia extensively studied the diversity of butterflies in hill dipterocarp forests (Aqilah et al. 2018; Norradihah et al. 2020), national parks (Norradihah et al. 2018; Yap et al. 2018), islands (Fathihi-Hakimi 2017) and lakes (Cheng et al. 2015). Sungai Petani is a city in the district of Kuala Muda, Kedah, Malaysia. Bukit $\mathrm{H}$ and Taman Jubli Perak are two recreational areas that are located in Sungai Petani. Taman Jubli Perak is an urban park purposely built for sports and recreational activities, while Bukit $\mathrm{H}$ is a lowland forest fragmented by tracking trails for hiking activity. Both recreational areas have different types of vegetation.

Currently, there is no previous study that exists in both areas. Most of the previous studies in Malaysia have focused on primary forests. The only record of the diversity of butterflies in Kedah can be found from a previous study by Norela et al. (2009) at Sungai Sedim Forest Reserve. Thus, the lack of biodiversity data, especially on the butterflies in these areas, can be one of the challenges in managing and protecting these areas. Thus, the main objectives of this study were to determine and compare the diversity of butterflies in two recreational areas at Sungai Petani, Kedah, Peninsular Malaysia. This study will contribute to the first record of butterflies in Sungai Petani, Kedah. Indirectly, this study will propose better 
management of these recreational areas in the future. Hopefully, the baseline data from this study will inspire other researchers to participate in any research related to the diversity of butterflies in Sungai Petani, Kedah.

\section{MATERIALS AND METHODS}

\section{Study area}

The study was carried out in the northern region of Peninsular Malaysia, which is Sungai Petani, Kedah $\left(5.64070^{\circ} \mathrm{N}, 100.5010^{\circ} \mathrm{E}\right.$ ) (Figure 1). The study was conducted in two recreational areas, namely Bukit $\mathrm{H}$ $\left(5.6059^{\circ} \mathrm{N}, 100.4599^{\circ} \mathrm{E}\right)$ and Taman Jubli Perak $\left(5.6467^{\circ} \mathrm{N}\right.$, $100.4865^{\circ} \mathrm{E}$ ) (Figure 2). Bukit $\mathrm{H}$ is a lowland forest with an elevation of $207.4 \mathrm{~m}$ asl. Bukit $\mathrm{H}$ is surrounded by orchard plantations such as jackfruit (Artocarpus heterophyllus) and stink bean (Parkia speciosa). Taman Jubli Perak is an urban park that is surrounded by vegetation such as ornamental cycad species and sago palm (Cycas revoluta) and also has an artificial pond.

\section{Procedures}

Sampling method

This research was conducted following the Guidelines for Research Ethics of Universiti Malaysia Terengganu. The samplings sessions were only performed for three consecutive months from January until March 2021 with nine sampling days per sampling site. There was a limitation with the sampling duration because of the government's Movement Control Order (MCO) due to the pandemic of Covid-19. Visual Encounter Survey (VES) was chosen as a sampling method. VES is a powerful active sampling method used to estimate butterflies' species richness and abundance (Kadlec et al. 2012). Although this method was originally developed for herpetofauna (Flint and Harris 2005), benefits associated with VES can easily be applied to grassland butterflies that are hard to detect or occur at low abundances (Bried and Pellet 2012). The VES method allows observers to search in areas where butterflies are more likely to be found. The surveys were carried out at each study area from 9 am to 11 am for the morning session and $12 \mathrm{pm}$ to $2 \mathrm{pm}$ for the evening session.

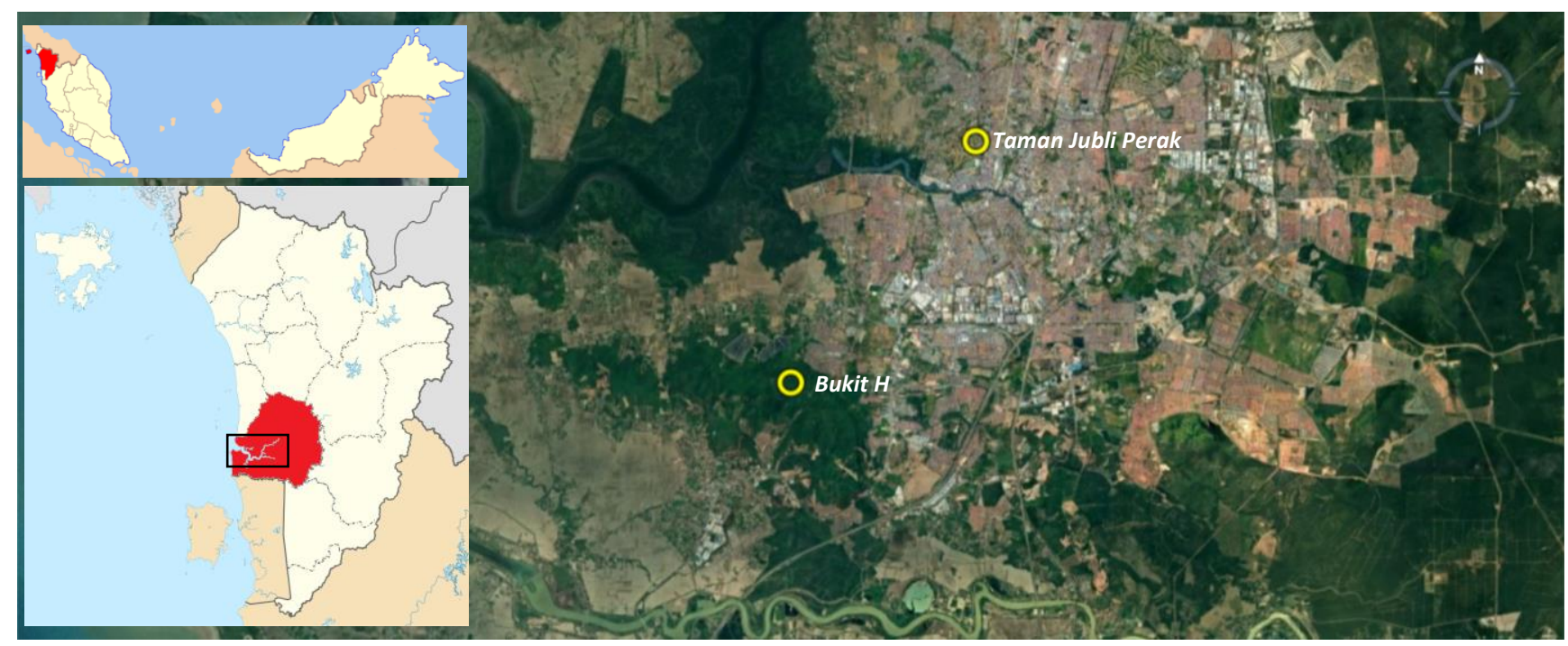

Figure 1. Location of Bukit H and Taman Jubli Perak at Sungai Petani Village, Kedah, Malaysia
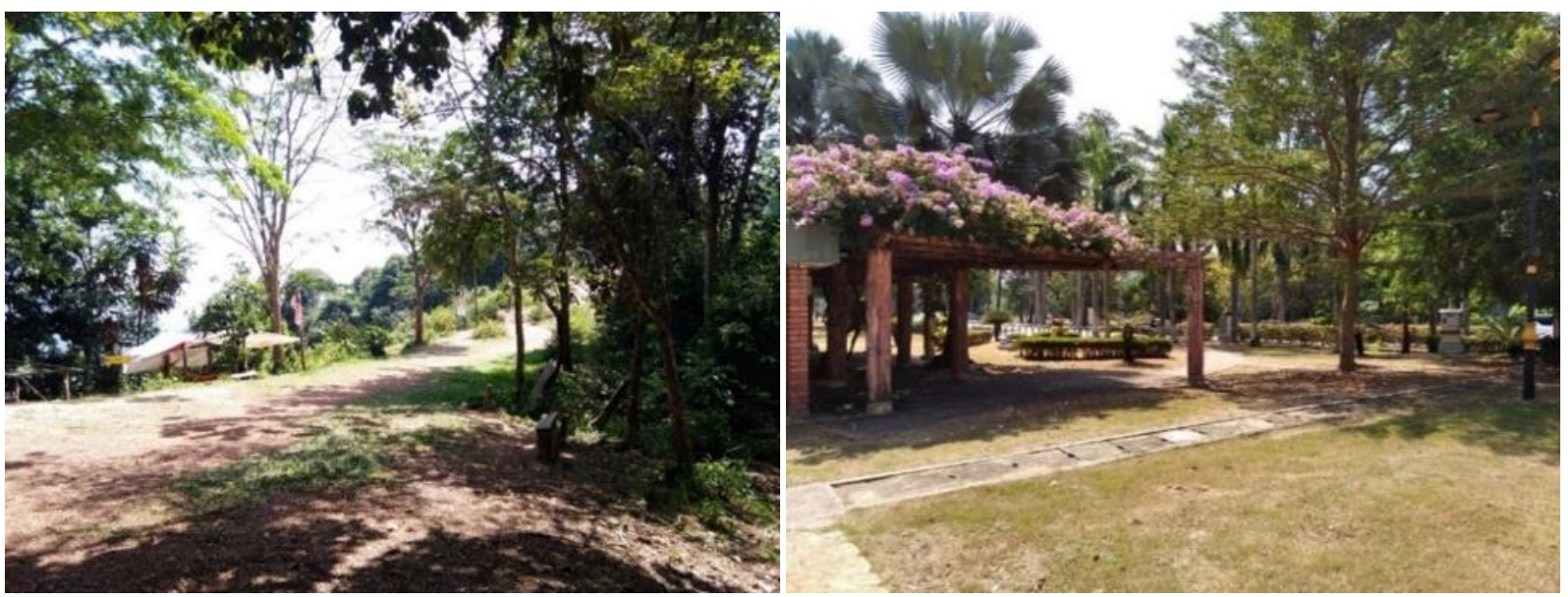

Figure 2. The study site in Bukit H (left) and Taman Jubli Perak (right), Sungai Petani Village, Kedah, Malaysia 
A total of 36 sampling hours were performed at each study area. The butterflies were sampled by two researchers along the different tracking trails at Bukit $\mathrm{H}$ and along an existing trail at Taman Jubli Perak. The butterflies were captured using a sweep net. Butterflies were identified in the field whenever possible. Each of the captured butterflies was identified by referring to the iNaturalist (2021) and Kirton (2014). Only one adult individual of each species was kept as a reference specimen, while others were photographed and released back. All specimens collected were brought to the laboratory, prepared, mounted, dried and stored as a reference collection at Makmal Biologi Umum, Faculty of Science and Marine Environment, Universiti Malaysia Terengganu.

\section{Data analysis}

Species diversity was calculated using ecological indices such as Shannon Index $\left(\mathrm{H}^{\prime}\right)$ and Simpson Index (1D), while Margalef Index and Menhinick Index were used to measure the species richness. Species evenness was measured using Equitability Index. A rank abundance curve (RAC) or Whittaker plot is a curve that was used to show the relative species abundance in this study. RAC also was used to visualize the species richness and species evenness. Species accumulation curves (SAC) graph was used to determine the sampling effort of two study sites. The Shannon and Simpson indices values were used to compare the diversity of butterflies between Bukit $\mathrm{H}$ and Taman Jubli Perak by using the diversity t-test. Prior to the t-test, the normality test was conducted using Shapiro-Wilk using the SPSS version 27 and the data were found normally distributed. From the t-test, the species diversity between the two study areas was considered significantly different when $\mathrm{p}<0.05$. Except for the normality test, all the data was analyzed using Paleontological Statistic (PAST) version 4.05.

\section{RESULTS AND DISCUSSION}

\section{Composition of butterflies}

A total of 145 individuals were collected at Bukit $\mathrm{H}$ (BH) and Taman Jubli Perak (TJP) in Sungai Petani, Kedah. Based on Table 1, the number of species at TJP (9 species) was higher compared to $\mathrm{BH}$ ( 8 species). The total number of individuals recorded from TJP ( 80 individuals) was higher compared to $\mathrm{BH}$ (65 individuals). The total species recorded from both $\mathrm{BH}$ and TJP were 13 from four families, namely Lycaenidae, Nymphalidae, Papilionidae and Pieridae. The highest number of butterfly species for Bukit $\mathrm{H}$ belongs to family Nymphalidae (5 species; $56 \%$ ), followed by Papilionidae (2 species; 22\%), Pieridae and Lycaenidae (two species; 11\% each) (Figure 3). For Taman Jubli Perak, the highest number of butterfly species belongs to family Nymphalidae (five species; 56\%), followed by Pieridae (two species; 22\%), and the least common was family Lycaenidae and Papilionidae (two species; $11 \%$ each) (Figure 4).

Table 2. Ecological indices for Bukit $\mathrm{H}$ and Taman Jubli Perak, Kedah, Malaysia

\begin{tabular}{lcc}
\hline & Bukit H & Taman Jubli Perak \\
\hline Taxa (S) & 8 & 9 \\
Individuals & 65 & 80 \\
Dominance, D & 0.450 & 0.360 \\
Simpson, 1-D & 0.550 & 0.640 \\
Shannon, H' & 1.213 & 1.433 \\
Evenness, e^H/S & 0.421 & 0.466 \\
Menhinick Index, R2 & 0.992 & 1.006 \\
Margalef Index, R1 & 1.677 & 1.826 \\
Equitability, J & 0.583 & 0.652 \\
Chao-1 & 10 & 11 \\
\hline
\end{tabular}

Table 1. Composition of butterflies at two recreational areas in Sungai Petani, Kedah, Malaysia

\begin{tabular}{|c|c|c|c|c|}
\hline Family & Species & Bukit H & $\begin{array}{l}\text { Taman Jubli } \\
\text { Perak }\end{array}$ & Total \\
\hline Lycaenidae & Chilades pandava & 42 & 45 & 87 \\
\hline \multirow{8}{*}{ Nymphalidae } & Acraea terpiscore & 0 & 6 & 6 \\
\hline & Euploea mulciber mulciber & 1 & 0 & 1 \\
\hline & Hypolimnas bolina bolina & 4 & 1 & 5 \\
\hline & Ideopsis vulgaris macrina & 4 & 0 & 4 \\
\hline & Junonia orithya wallacei & 2 & 4 & 6 \\
\hline & Neptis hylas (Linnaeus) papaja & 10 & 0 & 10 \\
\hline & Ypthima pandocus corticaria & 0 & 1 & 1 \\
\hline & Ypthima huebneri & 0 & 2 & 2 \\
\hline \multirow[t]{2}{*}{ Papilionidae } & Papilio demoleus malayanus & 1 & 1 & 2 \\
\hline & Pathysa antiphates itamputi & 1 & 0 & 1 \\
\hline \multirow[t]{2}{*}{ Pieridae } & Appias libythea olferna & 0 & 13 & 13 \\
\hline & Leptosia nina nina & 0 & 7 & 7 \\
\hline Total & 13 & 65 & 80 & 145 \\
\hline
\end{tabular}




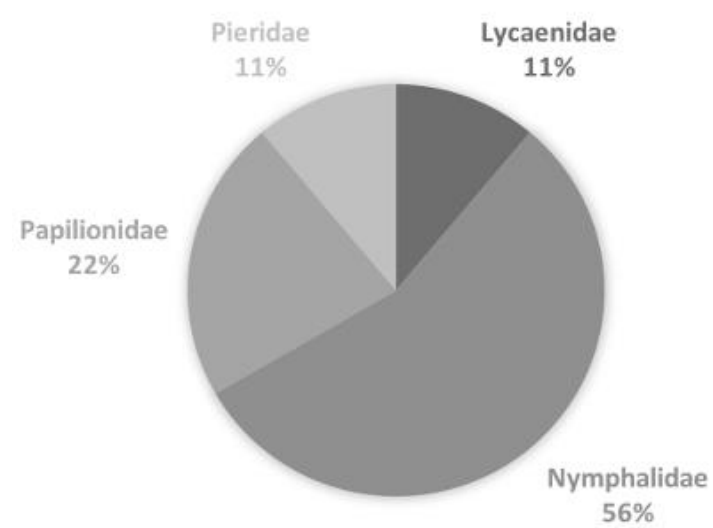

Figure 3. Composition of butterfly species according to families for Bukit H, Kedah, Malaysia

\section{Rank abundance curve (RAC)}

Based on Figure 5, Chilades pandava from the family Lycaenidae was the most abundant species at both Bukit $\mathrm{H}$ and Taman Jubli Perak with a total of 42 and 45 individuals, respectively. $\mathrm{BH}$ and TJP recorded three singleton species which were Euploea mulciber mulciber, Pathysa antiphates itamputi and Papilio demoleus malayanus at BH while Hypolimnas bolina bolina, Ypthima pandocus corticaria and P. demoleus malayanus at TJP.

\section{Species accumulation curve (SAC)}

Figure 6 shows the species accumulation curves for Bukit $\mathrm{H}$ and Taman Jubli Perak. The species accumulation curves were still steeply increasing and not leveling off in both recreational areas indicating that more species will be recorded with the increasing sampling effort. Chao-1 analysis (Table 2) supported this hypothesis that about ten species could be collected in Bukit $\mathrm{H}$ and 11 species for Taman Jubli Perak.

\section{Rarefaction}

Figure 7 shows rarefaction curves to compare the species captured in Bukit H (BH) and Taman Jubli Perak

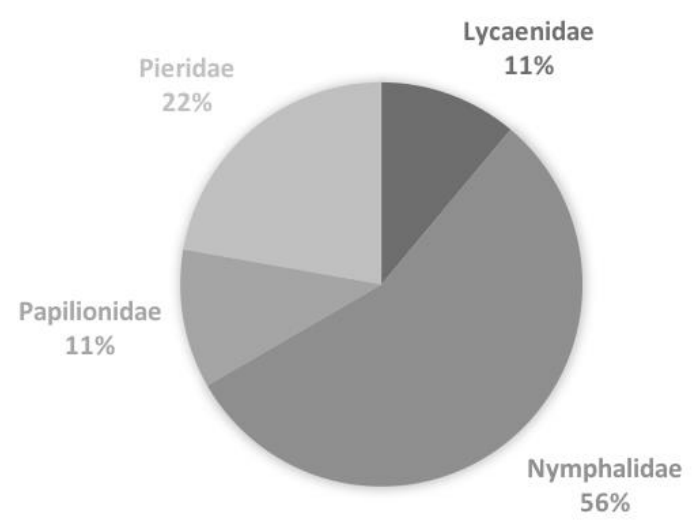

Figure 4. Composition of butterfly species according to families for Taman Jubli Perak, Kedah, Malaysia

(TJP). Both curves were still not reaching an asymptote and still grew rapidly, indicating that there are species that still were not found from this study. Since $95 \%$ confident intervals of Bukit $\mathrm{H}$ and Taman Jubli Perak were overlapped, there was no significant difference in species richness between these two study areas.

\section{Diversity T-test}

The comparison of diversity was determined using diversity t-test analysis. Shannon and Simpson's indices were used to compare the diversity in both study areas. Bukit $\mathrm{H}$ and Taman Jubli Perak recorded no significant diversity difference as the $\mathrm{p}$-value was more than 0.05 . For the Shannon index, value of t: -1.144 , d.f.: 1 , p: 0.254 while for the Simpson index, value of t:1.072, d.f.:1, p: 0.286 .

\section{Checklist of butterflies in Kedah}

A checklist of butterflies in Kedah was presented by comparing the results from this study with the previous study conducted in Sungai Sedim Reserve Forest (SSRF) by Norela (2009) (Table 3).

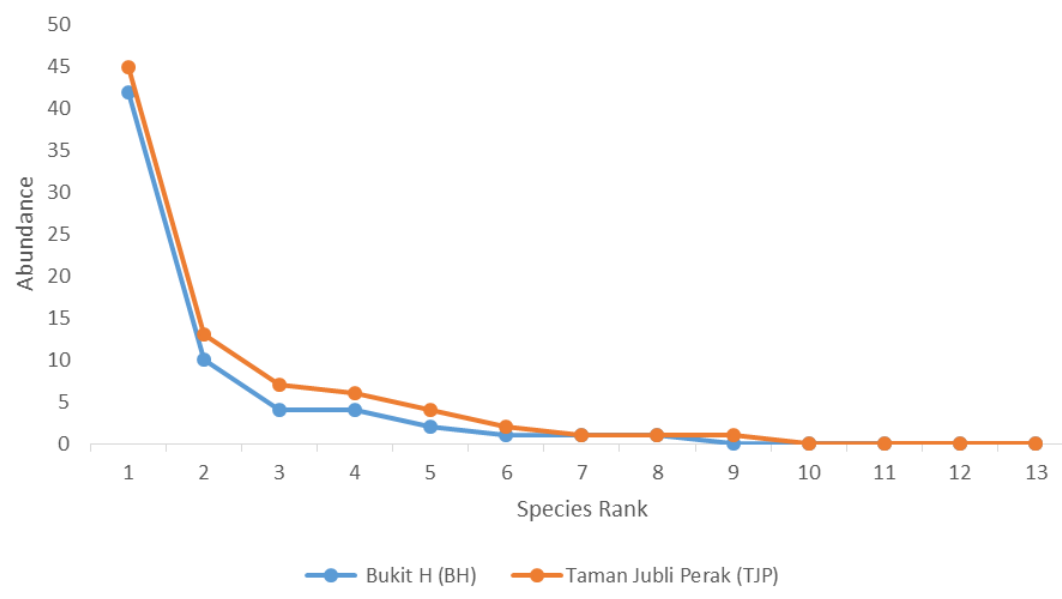

Figure 5. Rank abundance curve (RAC) of Bukit H and Taman Jubli Perak, Kedah, Malaysia 


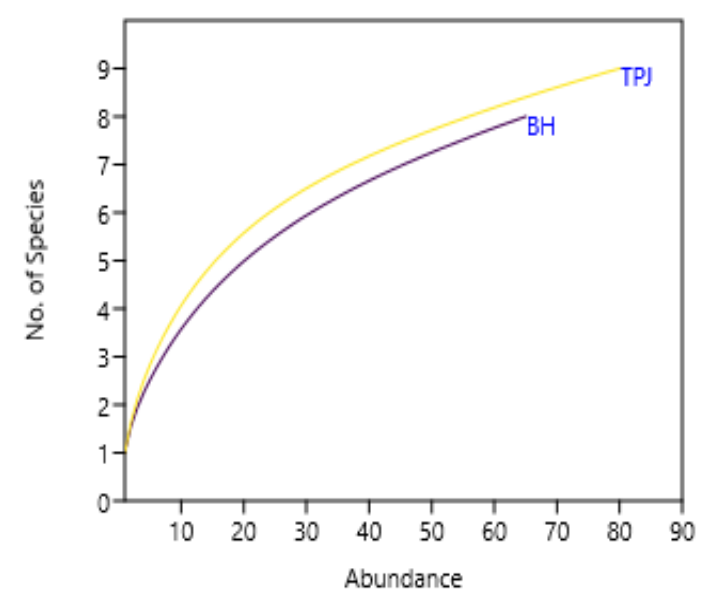

Figure 6. Species accumulation curves (SAC) of Bukit $\mathrm{H}(\mathrm{BH})$ and Taman Jubli Perak (TJP), Kedah, Malaysia

\section{Discussion}

A total of 145 individuals belonging to 13 species from four families were recorded at two recreational areas in Sungai Petani (Table 1). A previous study by Aqilah et al. (2018) in Bukit Soga, Johor that is located in the southern part of Peninsular Malaysia, recorded a greater result with higher species richness (43 species) but had a lower total number of individuals ( 88 individuals) compared to this study. The differences in the species richness and abundance of butterflies are influenced by the type of vegetation, host plant resources, and environmental conditions (Norradihah et al. 2020). According to Pyrcz et al. (2009), the type of vegetation plays an important role in the diversity of butterflies, abundance and evenness, where changes in vegetation structure and lower plant diversity at higher elevations can cause a decline in the number of Lepidopteran. The high species richness from the previous study may be due to the type of vegetation in which Bukit Soga was predominantly with native plants such as Shorea maxwelliana, Shorea leprosula and Shorea parvitalia. Bukit Soga also is surrounded by ornamental and herbs plants. According to Subedi et al. (2020), a variety and higher plant species richness will increase butterfly diversity. As a comparison, the study by Aqilah et al. (2018) had a similar sampling effort with this study with a total of nine sampling days per sampling area. From four families captured, Nymphalidae was the most dominant family as they are known as the largest family of butterflies in the world that comprise over 7000 species under 16 subfamilies (Suhairiza et al. 2017). The other studies of butterflies by Nur Afny and Amirrudin (2014), Aqilah et al. (2019) and Fathihi-Hakimi et al. (2017) also found similar results. Besides, Nymphalidae is also known as polyphagous insects, which they can survive in all kinds of habitats (Wang et al. 2017). According to Raut and Pendharkar (2010), Nymphalidae is a strong and active flier where they can find food resources within large areas.

Chilades pandava from the family Lycaenidae was the most dominant species in both study areas with different

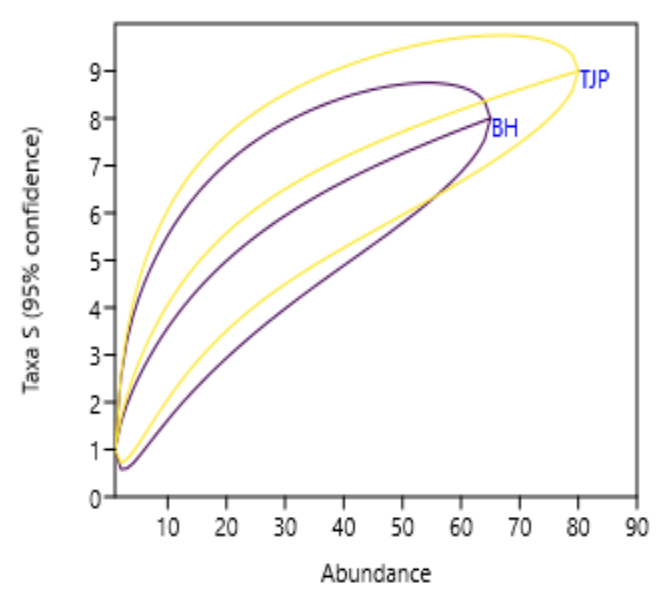

Figure 7. Rarefaction curves for two recreational areas in Sungai Petani, Kedah, Malaysia. BH: Bukit H, TJP: Taman Jubli Perak, Kedah, Malaysia

preferred vegetation as food sources. In this study, $C$. pandava found at Taman Jubli Perak (TJP) mostly perched on ornamental cycad species, Sago palms (Cycas revoluta). This finding was supported by Kirton (2014) that also found that Sago palms can be the host plant for $C$. pandava. Sago plants act as food resources to the caterpillar of $C$. pandava as they feed on the young leaves or soft tissue of sago palms (Naik et al. 2014). The caterpillars of butterfly C. pandava feed on numerous sago palms while the larvae bored into young shoots (Fric et al. 2014). At Bukit $\mathrm{H}(\mathrm{BH}), C$. pandava was captured in areas that were close to the ground. $C$. pandava prefers vegetation structures such as shrubs, grass and lower ground plants due to their weaker flight ability compared to other species. Next, Appias libythea olferna, commonly known as the Striped Albatross, was the second most common species found at TJP, with 13 individuals. However, A. libythea olferna was not presented at $\mathrm{BH}$. This species was hard to capture as they are fast flying and among the most active insect in sunny weather. A. libythea olferna is rare in Peninsular Malaysia. However, in the early 1980s, it became one of the most common butterflies in the gardens and along roadsides. There were three singleton species captured from this study which were Euploea mulciber mulciber, Ypthima pandocus corticaria and Pathysa antiphates itamputi. According to The International Union for Conservation of Nature (IUCN) Red List of Threatened Species (2021), all the species caught in this study are placed in the Least Concern (LC) category.

The total number of species recorded also varied between the sampling months. In this study, the highest number of butterfly species were recorded during the dry season in March due to the favorable weather conditions and availability of food sources during those times, possibly enhancing the presence of butterflies, especially in TJP. In tropical areas, the phenology of individual insect species and the whole ecosystem follow the regional seasonality typically represented by swapping of the wet and dry seasons (Kishimoto-Yamada and Itioka 2015). 
Table 3. The latest checklist of butterfly species in Kedah, Malaysia

\begin{tabular}{|c|c|c|c|}
\hline Family+species name & Bukit H & $\begin{array}{c}\text { Taman } \\
\text { Jubli } \\
\text { Perak }\end{array}$ & $\begin{array}{c}\text { Sungai } \\
\text { Sedim } \\
\text { Reserve } \\
\text { Forest }\end{array}$ \\
\hline
\end{tabular}

\section{Family Lycaenidae}

Abisara saturata kausambioides

Abisara savitri savitri

Arhopala acta

Catochrysops strabo strabo

Chilades pandava

Chliaria kina celastroides

Eooxylides tharis distanti

Hypolycaena merguia skapane

Miletus chinensis learchus

Paralaxita orphan laocoon

\section{Family Nymphalidae}

Acraea terpsicore

Agatasa calydonia calydonia

Cethosia penthesilea

Cirrochroa orissa orissa

Cupha erymanthis lotis

Cyrestis themire themire

Danaus chrysippus chrysippus

Elymnias hypermnesta tinctoria

Euploea mulciber mulciber

Euploea radamanthus radamanthus

Euthalia evelina compta

Hypolimnas bolina bolina

Hypolimnas bolina jacintha

Ideopsis similis persimilis

Ideopsis vulgaris macrina

Junonia orithya wallacei

Lasippa tiga siaka

Melantis ieda ieda

Moduza procris milona

Mycalesis fusca fusca

Mycalesis horsfieldi hermana

Mycalesis intermedia distanti

Mycalesis maianeas maianeas

Mycalesis mineus marcomalayana

Mycalesis orseis nautilus

Mycalesis visala phamis

Neorina iowii neophyte

Neptis hylas (Linnaeus) papaja

Orsotriaena medus cinetea

Pantoporia sandaka sandaka

Parantica aspasia aspasia

Tanaecia aruna aruna

Tanaecia flora flora

Ypthima huebneri

Yptima fasciata torone

Yptima pandocus corticaria

Yptima savara tonkiniana

Zeuxidia doubledayi doubledayi

\section{Family Papilionidae}

Papilio demoleus malayanus

Papilio polytes romulus

Parides nox erebus

Pathysa antiphates itamputi

Triodes amphrysus ruficollis
Family Pieridae

Appias libythea olferna

Eurema ada iona

Eurema andersonii andersonii

Eurema hecabe contubernalis

Eurema lacteola lacteola

Eurema sari sodalis

Eurema simulatrix littorea

Eurema simulatrix tecmessa

Gandaca harina distanti

Hebomola glaucippe aturia

Ixias pyrene birdi

Leptosia nina nina

Pareronia valeria lutescens

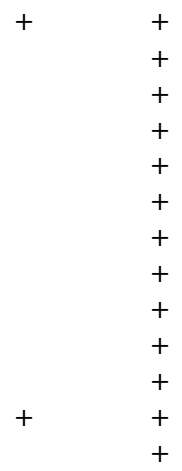

Family Hesperiidae

Koruthaialos sindu sindu

Quedara monteithi monteithi

$+$

Note: +: indicate the presence of species

Various tropical areas, usually with one or two annual rainy seasons, exhibit annual or biannual peaks of adult Lepidoptera species richness, as well as phenological patterns in their communities' composition (Grøtan et al. 2014). Both temperature and rainfall fluctuations were revealed to influence lepidopterans' abundances and species richness (Kishimoto-Yamada and Itioka 2015). Mass flowering in the late rainy and high-dry seasons was described to support the diversity of adult Lepidoptera (Cruz-Neto et al. 2011). In this study, the total catch of the most abundant species, Chilades pandava was 87 individuals. Observations demonstrated that the highest abundance for this species was due to the flowering of cycad trees as their main food source during the sampling time in March. However, in this study, some species that were considered as common were found absent or displayed very low abundance. Ypthima pandocus corticaria (Nymphalidae) is one of the larger and most common Ypthima butterflies in Malaysia and was stated to be the most common butterfly in the eastern tropics where it occurs at all altitudes such as in the forests, in secondary growths and even in the gardens (Corbet and Pendlebury 1992). Interestingly, in this study, this species was only found once at TJP. Eurema hecabe contubernalis that was also stated to be the most common butterfly in the tropics, was also not recorded in this study. This might be due to the extreme heat in the dry season that might restrict the flight activities of the species and reduce the larval hostplant quality (Suhairiza et al. 2017).

Ecological indices were used to estimate the diversity and richness of the butterflies at Bukit $\mathrm{H}$ and Taman Jubli Perak. Based on Table 2, diversity indices such as Shannon and Evenness Index at TJP were higher compared to BH. However, the diversity at both sites was interpreted as moderately low due to the low species richness. This may be due to the lack of sampling effort because of the Movement Control Order (MCO) restriction due to the pandemic situation. Furthermore, the timing of observations might be another reason for the fewer sightings since this study period was concentrated only four 
hours per sampling session. Therefore, intensive sampling efforts such as by covering more places, using various capture techniques and longer sampling periods are suggested to increase the species richness. The use of rotten fruits as bait is recommended to attract and capture especially fast-flying butterflies. Based on the diversity $\mathrm{T}$ test result from Table 3, the p-value showed no significant differences for both Simpson Index and Shannon Index between both study areas as $\mathrm{p}>0.05$. From Figure 6 , more butterfly species can be discovered at $\mathrm{BH}$ and TJP if the sampling efforts increase as the curves of the species accumulation graph were steeply increasing and still not leveling off for both study sites. Based on Figure 7, the rarefaction curves of $\mathrm{BH}$ and TJP were overlapped with each other, which means that there was no significant difference in species richness of butterflies among both study areas.

There are still many parts of Kedah that have never been documented. The only previous study of butterflies in Kedah was conducted at Sungai Sedim Forest Reserve (SSFR) by Norela (2009). The findings from this study were compiled together with the study from SSFR to provide a checklist of butterflies in Kedah (Table 3). From this comparison, SSFR (59 species) recorded higher species richness compared to this study (13 species). This may be due to the fact that SSRF is a disturbed dipterocarp forest that has been converted into a recreational area and some parts of the forest have been planted with ornamental and landscape species that can attract many species of butterfly in this area. Other than that, the study by Norela (2009) used a food-baited method that can catch fast-flying butterflies easily. To date, the current number of species recorded in Kedah is 67 species, adding eight new species from $\mathrm{BH}$ and TJP, representing $6 \%$ of the total of butterfly species in Peninsular Malaysia (1038 species; Eliot and Kirton 2000). In terms of species composition, there were two similar species (Euploea mulciber mulciber and Pathysa antiphates itamputi) between BH and SSRF and three species (Ypthima pandocus corticaria, Appias libythea olferna and Leptosia nina nina) between TJP and SSRF.

Diversity indices $\left(\mathrm{H}^{\prime}\right)$ are often computed as a measure of species diversity of a community. It provides information about community composition than simply observed species (i.e., the number of species recorded) that takes into consideration the relative abundances of different species in the sample (Nur Afny and Amirrudin 2014). In this study, the values of $\mathrm{H}^{\prime}$ were considered as moderately low in both study areas. This gave a strong indication that certain butterfly species dominated the catch. These may be related to the disturbed environment and vegetation structure that cannot support more butterfly species $(\mathrm{Vu}$ and $\mathrm{Vu}$ 2011). The findings from this study will be baseline data on the diversity of butterflies in Sungai Petani, Kedah and hopefully, will be an important reference to future research. The findings from this study may also be used to increase the management, and public awareness and knowledge about the importance to manage anthropogenic activities and the landscape of the recreational parks to ensure that the vegetations that are planted there are friendly to Lepidoptera community and indirectly will preserve and conserve the Lepidoptera species in Sungai Petani, Kedah.

\section{ACKNOWLEDGEMENTS}

The authors would like to express the highest gratitude to the Universiti Malaysia Terengganu for the contributions of field equipment and financial support.

\section{REFERENCES}

Aqilah AAR, Maryati M, Linatoc AC. 2018. Butterfly (Lepidoptera: Rhophalocera) diversity in Bukit Soga, the green lung of Batu Pahat, Malaysia. AIP Conf Proc 2002: 020005. DOI: 10.1063/1.5050101.

Aqilah AAR, Maryati M, Shahrir-Azrin MS. 2019. Diversity and species composition of butterflies (Lepidoptera: Papilionoidae) in Taka Melor Amenity Forest, Labis Forest, Segamat, Johor, Malaysia. Serangga 24 (2): 72-80. DOI: 10.1088/1755-1315/736/1/012058.

Bonebrake TC, Cooper DS. 2014. A Hollywood drama of butterfly extirpation and persistence over a century of urbanization. J Insect Conserv 18 (4): 683-692. DOI: 10.1007/s10841-014-9675-z.

Bried JT, Pellet J. 2012. Optimal design of butterfly occupancy surveys and testing if occupancy converts to abundance for sparse populations. J Insect Conserv 16: 489-499. DOI: 10.1007/s10841011-9435-2.

Cheng TC, Tajuddin S, Mahat MF, Ean TP. 2015. A checklist of butterflies of Tasek Bera Ramsar Site, Pahang, Malaysia. J Wild Parks 30: 15-26.

Corbet AS, Pendleburt HM. 1992. The Butterflies of the Malay Peninsula. Malayan Nature Society, Kuala Lumpur.

Cruz-Neto O, Machado IC, Duarte JA, Lopes AV. 2011. Synchronous phenology of hawkmoths (Sphingidae) and Inga species (FabaceaeMimosoideae): Implications for the restoration of the Atlantic forest of northeastern Brazil. Biodivers Conserv 20: 751-765. DOI: 10.1007/s10531-010-9975-x.

Durairaj P, Sinha B. 2015. Review of butterflies (Lepidoptera: Rhopalocera) from Arunachal Pradesh: Conservation status and importance of research in protected areas. Zool Surv India 61-77.

Eliot JN, Kirton, LG. 2000. The revisional notes and nomenclatural changes of some Peninsular Malaysia butterflies. Malay Nat J 54: 131-145.

Fathihi-Hakimi R, Muhamad-Aidil Z, Amalina A, Azizah A, Elizabeth P, Abdullah MT. 2017. Checklist of butterflies in Pulau Perhentian and Pulau Bidong, Terengganu. J Sustain Sci Manag 12 (1): 40-48.

Flint WD, Harris N, 2005. The efficacy of visual encounter surveys for population monitoring of Plethodon punctatus (Caudata: Plethodontidae). J Herpetol 39: 578-584. DOI: 10.1670/255-04A.1.

Fric Z, Dickinson R, Fetouh G, Larsen TB, Schon W, Wiemers M. 2014. First record of the cycad blue, Chilades pandava, in Egypt-A new invasive butterfly species in the Mediterranean region and on the African continent (Lepidoptera: Lycaenidae). Afr Entomol 22: 315 319. DOI: $10.4001 / 003.022 .0205$.

Grøtan V, Lande R, Chacon IA, Devries PJ. 2014. Seasonal cycles of and similarity in a Central American rainforest butterfly community. Ecogr 37: 509-516. DOI: 10.1111/ecog.00635.

Hering CM. 2012. Differential Attraction of Insect Orders to Different Wavelengths of Light. University of North Carolina, Charlotte, NC.

iNaturalist. 2021. Butterfly of Malaysia. https://www.inaturalist.org/projects/butterflies-of-malaysia68a82348-090c-4752-b05c-ae38170b6324?tab=species.

IUCN Red List of Threatened Species. https://www.iucnredlist.org/.

Kadlec T, Tropek R, Konvicka M. 2012. Timed surveys and transect walks as comparable methods for monitoring butterflies in small plots. J Insect Conserv 16: 275-280. DOI: 10.1007/s10841-011-94147.

Khan MI, Ullah H, Suleman, Khan MAS, Muhammad N, Zada S, Hussain S. 2015. A review on diversity of butterfly fauna in Pakistan. World J Zool 10 (4): 313-317. DOI: 10.5829/idosi.wjz.2015.10.4.9659. 
Kirton LG. 2014. A Naturalist's Guide to the Butterflies of Peninsular Malaysia, Singapore and Thailand. $2^{\text {nd }}$ ed. John Beaufoy Publishing, United Kingdom.

Kishimoto-Yamada K, Itioka T. 2015. How much have we learned about seasonality in tropical insect abundance since Wolda (1988)? Entomol Sci 18: 407-419. DOI: 10.1111/ens.12134.

Kocher SD, William EH. 2000. The diversity and abundance of North American butterflies vary with habitat disturbance and geography. J Biogeogr 27: 785-794. DOI: 10.1046/j.1365-2699.2000.00454.x.

Naik SO, Jayashankar M, Chandrashekhariah M, Sridhar V, Chakravarthy AK. 2014. Cycad blue butterfly Chilades pandava pandava Horsfield, 1829 (Lepidoptera: Lycaenidae) infestation on Cycas revoluta in Bengaluru. Uttar Pradesh J Zool 34: 137-141.

Nelson SM. 2007. Butterflies (Papilionoidea and Hesperioidea) as potential ecological indicators of riparian quality in the semi-arid western United States. Ecol Indic 7 (2): 469-480. DOI: 10.1016/j.ecolind.2006.05.004.

Norela S, Md Said S, Abdullah M, Mohamed AA. 2009. Butterfly fauna (Lepidoptera: Rhopalocera) of the Sungai Sedim Forest Reserve in Kedah, Malaysia. J Wildl Parks 26: 21-32.

Norradihah I, Aqilah AAR, Maryati M, Bakar MFA, Tokiman L. 2020. Butterfly as bioindicator for development of conservation areas in Bukit Reban Kambing, Bukit Belading and Bukit Tukau, Johor, Malaysia. Biodiversitas 21 (1): 334-344. DOI: 10.13057/biodiv/d210141.

Norradihah I, Maryati M, Phon CK, Tokiman L. 2018. Spatial distribution of butterfly (Lepidoptera: Papilionoidea) in Taman Negara Johor Endau Rompin (Peta), Mersing, Johor, Malaysia. J Sci Tech 10 (2): 17-21. DOI: 10.30880/jst.2018.10.02.003.

Nur Afny SAZ, Amirrudin A. 2014. Checklist of butterfly fauna at Kuala Lompat, Krau Wildlife Reserve, Pahang, Malaysia. J Wildl Parks 28: 63-72.

Pyrcz TW, Wojtusiak, Garlacz J. 2009. Diversity and altitudinal distribution pattern of Pronophilina butterflies in north-western
Ecuador (Nymphalidae: Satyrinae). Neotrop-Entomol 38 (6): 716726. DOI: 10.1590/S1519-566X2009000600003.

Raut NB, Pendharkar A. 2010. Butterfly (Rhopalocera) fauna of Maharashtra Nature Park, Mumbai, Maharashra, India. J Species Lists Distrib 6 (1): 22-25. DOI: 10.15560/6.1.022.

Sánchez-Bayo F, Wyckhuys KAG. 2019. Worldwide decline of the entomofauna: A review of its drivers. Biol Conserv 232: 8-27. DOI: 10.1016/J.BIOCON.2019.01.020.

Stansfield WD. 2016. Online resources for distinguishing butterflies from moths \& other such common animal comparisons. The Am Biol Teach 78 (4): 335-337. DOI: 10.1525/abt.2016.78.4.335.

Subedi B, Stewart AB, Neupane B, Ghimire S, Adhikari H. 2020. Butterfly species diversity and their floral preferences in the Rupa Wetland of Nepal. Ecol Evol 11: 2086-2099. DOI: 10.1002/ece3.7177.

Suhairiza S, Aisyah Z, Azman S, Yaakob MZM, Juhary MAA, Norela S. 2017. Species diversity and abundance of butterfly (Lepidoptera: Rhopalocera) at different altitudes along the Raub Corridor to Fraser's Hill, Pahang, Malaysia. Serangga 22 (1): 123-145.

Vu LV, Vu CQ. 2011. Diversity pattern of butterfly communities (Lepidoptera; Papilionoidea) in different habitat types in a tropical rainforest of southern Vietnam. ISRN Zool 2011 (1): 1-8. DOI: $10.5402 / 2011 / 818545$.

Wang H, Holloway JD, Janz N, Braga MP, Wahlberg N, Wan M, Nylin S. 2017. Polyphagy and diversification in tussock moths: Support for the oscillation hypothesis from extreme generalists. Ecol Evol 7: 79757986.DOI: 10.1002/ece3.3350.

Williams AAE, Coppen RAM, Williams MS. 2018. A method for conducting mark-release-recapture studies of the graceful sun-moth Synemon gratiosa (Lepidoptera: Castniidae). Rec West Aust Mus 33: 181-186. DOI: 10.18195/issn.0312-3162.33(2).2018.181-186.

Yap GC, Muhammad HS, Chong JL. 2018. A preliminary butterfly (Lepidoptera) checklist of the Terengganu National Park, Peninsular Malaysia. Malay Nat J 70 (1): 67-70. 